\title{
REKAYASA NILAI PEMBUATAN TERHADAP WAKTU DAN SPESIFIKASI PEKERJA PADA PEMBANGUNAN PERUMAHAN PESONA TUGU RANTE RESIDENCE TYPE 45 KABUPATEN BLITAR
}

\author{
Sugianto \\ Universitas Islam Balitar \\ Jl. Majapahit 12A Blitar \\ deglengsujiwo@gmail.com
}

\begin{abstract}
Abstrak
due torecent economic situation, contractors have een required to be able to minimize cost and the same time to also maintain the quality of the project. One of the methods that can be apllied as an alternative to achieve it is value engineering. The aim of this studyis to apply this method in a construction project. The construction project of Housing development in charm tugu rante type 45 residence district blitar Rp $99,792,000.00$

Value engineering method consist of 4 ( five ) phases. It covers information phase, which contains of identification of the high-cost work and the unnecessary cost ( function analysis ); creative phase; analyzing phase which includes the selection of alternative dealing with the analysis of its benefit and cost, it project life cycle cost and the selection of alternatives by using AHP method; and Recommendation phase.

By implementing thismethod,the project cost can be minimized in 5 area of wark,woll work Rp1,902,459,wall strucco work Rp3,941,693, the work of the faundotion stone,soil excavation Rp211,616,excavation work Rp782,012,ceramic work $\mathrm{Rp} 294,775$. Thus total reduction cost that be achieved by using this method is upto
\end{abstract}

Keywords:engenering value Housing development

\section{PENDAHULUAN}

Pada pembangunan sebuah Perumahan, rencana anggaran biaya dihitung setelah perhitungan konstruksi bangunan. Hal tersebut terkait dalam pemilihan desain dan bahan yang digunakan dalam perencanaan konstruksi bangunan tersebut. Rencana Anggaran Biaya proyek bangunan gedung disusun seoptimal dan seefisien mungkin dengan mutu dan kualitas yang tetap terjamin. Pada beberapa bagian bangunan gedung ada yang memiliki biaya yang besar, namun bagian tersebut masih dapat dioptimalisasi dengan cara pengefisienan kembali. Aspek pembiayaan yang besar menjadi pusat perhatian untuk dilakukan analisa kembali dengan tujuan untuk mencari penghematan.

Hal tersebut memunculkan banyaknya lternatif-alternatif yang dijadikan dasar untuk melakukan kajian yang sifatnya tidak mengoreksi kesalahan-kesalahan 
yang dibuat perencana maupun mengoreksi perhitungannya namun lebih mengarah kepenghematan biaya upah pekerja Oleh karena itu diperlukan adanya suatu Rekayasa Nilai (Value Engineering) agar biaya-biaya dan usaha-usaha yang tidak diperlukan dapat dihilangkan sehingga nilai atau biaya proyek tersebut dapat berkurang.

\section{LANDASAN TEORI}

\subsection{Definisi Rekayasa Nilai}

Rekayasa Nilai adalah usaha yang terorganisasi secara sistematis dan mengaplikasikan suatu teknik yang telah diakui, yaitu teknik mengaplikasikan suatu produk atau jasa yang bertujuan memenuhi fungsi yang diperlukan dengan harga yang terendah (paling ekonomis) Dengan kata lain, Rekayasa Nilai bermaksud memberikan suatu yang optimal bagi sejumlah uang yang dikeluarkan, dengan memakai teknik yang sistematis untuk menganalisis dan mengendalikan total biaya produk. Rekayasa Nilai akan membantu membedakan dan memisahkan antara yang diperlukan dan tidak diperlukan, dimana dapat dikembangkan alternatif yang memenuhi keperluan (dan meninggalkan yang tidak perlu) dengan biaya terendah. Pada beberapa tahun terakhir ini penggunaan Value Engineering meningkat dengan pesat sekali, (Mandagi, 2010)

\subsection{Manfaat Penerapan Konsep Value Engineering Pada Sektor Konstruksi}

Dalam penerapan VE khusunya pada industri konstruksi manfaat secara umum yang dapat diberikan yaitu:

1Dapat mencegah dan mereduksi timbulnya potensi biaya yang tidak perlu (Loss Cost) pada item pekerjaan konstruksi.

2Dapat mencegah terjadinya pemebengkakan biaya pada akhir pelaksanaan proyek konstruksi.

3Dapat menciptakan peningkatan budaya, daya inovasi dan kreatifitas bagi para insinyur penyelenggara konstruksi baik dari lembaga konsultan, kontraktor maupun pihak pemilik proyek/owner.

4Dapat melahirkan para pakar-pakar Value Engineers Specialist sebagai suatu cabang ilmu keteknikan yang berorientasi kepada kinerja tim dari beberapa disiplin bidang keinsinyuran.

5Dapat menjadi suatu pembelajaran bagi pihak penyelenggara konstruksi bahwa proses perencanaan dan perancangan suatu proyek konstruksi harus dilakukan secara matang dan optimal dalam hal ini konsep penerapan VE dapat dilakukan pada tahap ini dikarenakan tingkat kompleksitas yang tinggi jika proses VE dilakukan pada tahap pelaksanaan konsruksi

Dalam realita di lapangan suatu proses rekayasa nilai dalam pelaksanaannya sering terbentur oleh pihak-pihak yang terlibat di dalamnya, misalnya jika konsultan perencana atau arsitek telah membuat suatu perencanaan teknis dan kemudian disisi lain pihak value engineer ingin mengubah desain tersebut dengan tujuan mereduksi 
biaya konstruksi atau pertimbangan lain, maka secara umum hal demikian dapat menyebabkan timbulnya konflik internal dan perbedaan presepsi dalam suatu organisasi proyek. Hal tersebut tidak perlu terjadi jika sebelumnya dilakukan koordinasi antara semua pihak baik owner/pemilik, konsultan, kontraktor dan tim VE sendiri agar tidak merugikan sesama pihak, dalam hal ini perlu pendekatan komunikasi serta pemahaman dalam penerapan proses value engineering.

Metode value engineering jika dipahami oleh semua pihak penyelenggara konstruksi sangat berguna dalam mengoptimalisasikan biaya konstruksi. Memang value engineering di Indonesia belum banyak yang mengetahui khususnya dalam kegiatan konstruksi, tetapi harapan saya kiranya ke depan aplikasi value engineering bukan menjadi ancaman oleh pihak pemilik, konsultan dan kontraktor tetapi lebih untuk manfaat bersama, kiranya semua pihak dalam penyelenggaraan konstruksi lebih paham pentingnya aplikasi value engineering di kemudian hari.

\subsubsection{Perinsip Dasar Rekayasa Nilai}

Tujuan utama menciptakan suatu produk pada dasarnya adalah agar produk yang dibuat dapat terjual dengan cepat, dengan keuntungan yang maksimal dan dapat memberikan kepuasan kepada konsumen. Dengan demikian para perancang produk (desain produk) seharusnya tidak men-ciptakan fungsifungsi produk maupun penggunaan bahan produksi yang berlebihan pada akhirnya tidak berguna dan harganya-pun tinggi. Jadi gagasan harus dikembangkan dengan bertitik tolak dari: (Dhanardono, 2008)

1.Penghematan biaya

Yaitu menggunakan biaya seminimal mungkin tanpa mengurangi fungsi dan kualitas dari suatu produk

2. Waktu

Yaitu memeanfaatkan waktu dengan sebaik mungkin, ini dimaksudkan menggunakan waktu yang minimal dengan mendapatkan hasil yang maksimal

3.Bahan

Yaitu menggunakan bahan yang benar-benar memenuhi fungsi maupun kualitas

\subsubsection{Rencana Kerja Rekayasa Nilai}

Rencana kerja (Job plan) adalah pendekatan sistematik dari Rekayasa Nilai. Rencana kerja ini merupakan rencana yang terarah untuk melaksanakan Rekayasa Nilai termasuk implementasi hasil Rekayasa Nilai tersebut. Rencana kerja juga menjadi penentu kunci keberhasilan dari studi Rekayasa Nilai. (Saptono, 2012) Melalui pendekatan rencana kerja Rekayasa Nilai inilah seluruh tahapan dalam penerapan Rekayasa Nilai dilakukan, mulai dari melakukan identifikasi item kerja dari keseluruhan proyek, menemukan item kerja dengan potensi dengan biaya yang tidak diperlukan, hingga mencari alternatif-alternatif baru secara kreatif untuk menampilkan fungsi yang sama diinginkan seperti desain sebelumnya. Rencana kerja ini juga membantu dalam menentukan bagian-bagian 
yang mempunyai biaya yang tinggi dibandingkan dengan fasilitas-fasilitas yang serupa. (Saptono, 2012)

Waktu Mengaplikasikan Value Engineering

Value Engineering Program dapat diaplikasikan pada setiap saat sepanjang waktu berlangsungnya proyek itu, dari awal hingga selesainya pelaksanaan pembangunan proyek tersebut. (Rh. Mitchell \& S. Chandra,1987)

Seringkali proyek telah berjalan tanpa diadakan Value Study. Hal yang demikian ini seharusnya tidak terjadi, adalah penting sekali bagi Value Consultant untuk menjamin dan meyakinkan bahwa setiap proyek akan dapat mencapai suatu penghematan biaya melalui usaha Value Engineering. Lebih praktis apabila Value Engineering dapat diaplikasikan pada saat tertentu dalam tahap perencanaan untuk mencapai hasil yang maksimal.

Waktu adalah sangat penting, secara umum bahwa Value Engineering Program harus dimulai sejak dini pada tahap konsep dan secara kontinyu pada interval sampai selesainya perencanaan.

\section{Tahap Perencanaan}

Aplikasi Value Engineering harus diusahakan pada tahap konsep perencanaan. Karena pada saat ini, kita mempunyai flexibilitas yang maksimal untuk mengadakan perubahan-perubahan tanpa menimbulkan biaya untuk redesign.Dengan berkembangnya proses perencanaan, biaya untuk mengadakan perubahan-perubahan akan bertambah, sampai akhirnya mencapai suatu titik dimana tidak ada penghematan yang dapat dicapai.

2 Tahap Akhir Perencanaan ( Late Design Stage)

Dengan kemajuan perencanaan dari konsep, programming, schematic, pengembangan ( design development), sampai ke detail perencanaan ( final design ), Value Engineering perlu menyertai kemajuan perencanaan ini. Terutama ValueEngineering analysis harus menyertai setiap penyerahan tahapan perencanaan itu agar dapat memberikan pengarahan kepada perencana dan menjamin bahwa pertimbangan dari segi nilai atau biaya telah dikemukakan kepada Pemilik Proyek guna mendapatkan perhatian didalam mengambil keputusannya

\subsection{Tahapan Rekayasa Nilai}

Suatu analisis rekayasa nilai yang dalam hal ini menyangkut proyek konstruksi setidaknya bisa mereduksi hingga 30\% dari biaya total jika dilakukan dengan baik. Sebagai contoh dalam proyek sebuah jembatan beton Prestrees Concrete ada bebrapa item pekerjaan yang jika kita lakukan suatu rekayasa nilai dapat menghemat biaya pelaksanaan, misalnya untuk item pekerjaan gelagar (Girder) jika dalam hal ini kita lakukan suatu inovasi dalam pelaksanaannya dengan metode tertentu kita dapat melakukan reduksi biaya, tentunya hal ini memerluhkan suatu inovasi dan kreatifitas dalam mengaplikasikannya yang tetap pada prinsip tidak menghilangkan Mutu, fungsi, manfaat dan estetika dari pekerjaan tersebut. Adapun 
Sugianto. 2017. Rekayasa Nilai Pembuatan Terhadap Waktu dan Spesifikasi Pekerja Pada

Pembangunan Perumahan pesona Tugu Rante Residence type 45 kabupaten blitar. Jurnal Qua Teknika, (2017), 7(1) : 31 41

tahapan -tahapan secara umum dalam suatu analisis rekayasa nilai Ada 6 tahapan rekayasa nilai (Saptono, 2012)

\subsection{Unsur-unsur Utama Value Engineering}

Value Engineering mempunyaibeberapa kemampuan yang dapat dipakai sebagai alat bagi Value Analysis. Kemampuan itu dikenal sebagai unsur-unsur utama dari Value Engineering, adapun unsur-unsur utama tersebut adalah sebagai berikut

1 Pemilihan proyek-proyek untuk Value Engineering Study

2 Penentuan harga untuk Value

3 Biaya Siklus Hidup (The Life Cycle Costing)

4 Fungsional Approach (The Functional Approach)

5 Functional Analysis System Technique (FAST)

6 Rencana Kerja Value Engineering

7 Kreatifitas

\subsection{Sebab-Sebab Timbulnya Biaya-Biaya Yang Tidak Diperlukan}

Ada beberapa sebab-sebab mengapa biaya yang tidak diperlukan ( unnecessary cost), atau nilai kurang ( poor value) timbul didalam design. Pemilik Proyek mempunyai pengaruh terhadap nilai dari suatu proyek, sebab mereka menetapkan criteria utama dari design, karena mereka mengoperasikan dan mengendalikan fasilitas-fasilitas tersebut. (Rh. Mitchell \& S. Chandra, 1987)

Menurut Dr. Ir. S. Chandra dalam bukunya "Aplikasi Value Engineering \& Analysis Pada Perencanaan Dan Pelaksanaan Untuk Mencapai Program Effisiensi”, timbulnya biaya yang tidak diperlukan atau Nilai Kurang, pada umumnya disebabkan oleh beberapa hal-hal yang tersebut dibawah ini :

1.Kekurangan Waktu

Setiap Perencana mempunyai batas waktu untuk menyerahkan hasil perencanaannya. Apabila ia tidak menyerahkan tepat pada waktunya, maka reputasinya akan terpengaruh. Dalam kata lain, perencana hanya memiliki waktu 2. Kekurangan Informasi

Material dan produk-produk baru terus menerus memasuki pasaran, dan tidak mungkin untuk mengetahui semua perubahan-perubahan ini.Demikian pula sulit untuk menerima semua produk yang baru itu sebelum terbukti integritasnya.

3. Kekurangan Ide

Setiap expert mempunyai spesialisasinya masing-masing, tidak ada orang yang dapat menguasai keahlian dalam semua bidang.

4. Kekurangan Biaya Perencanaan

Tidak menyediakan biaya yang semestinya untuk menyelesaikan suatu pekerjaan perencanaan dapat mempengaruhi hasil produk dari perencanaan tersebut. Jalan pintas untuk bekerja menurut dana dan waktu yang tersedia sering kali menambah biaya yang tidak diperlukan didalam perencanaan. Kekurangan biaya 
perencanaan adalah bagian yang kecil dari biaya proyek, sebaliknya sangat mempengaruhi biaya total dari seluruh proyek

\subsection{Keterlambatan Proyek}

Kusjadmikahadi (dalam Leonda 2008) bahwa, keterlambatan proyek konstruksi berarti bertambahnya waktu pelaksanaan penyelesaian proyek yang telah direncanakan dan tercantum dalam dokumen kontrak. Praboyo (1999), keterlambatan pelaksanaan proyek umumnya selalu menimbulkan akibat yang merugikan bagi pemilik maupun kontraktor karena dampak keterlambatan adalah konflik dan perdebatan tentang apa dan siapa yang menjadi penyebab, juga tuntutan waktu, dan biaya tambah.

\section{METODE PENELITIAN}

\subsection{Umum}

Metodologi penelitian adalah sekumpulan peraturan, kegiatan, dan prosedur yang digunakan oleh pelaku suatu disiplin ilmu. Metodologi juga merupakan analisis teoritis mengenai suatu cara atau metode. Penelitian merupak an suatu penyelidikan yang sistematis untuk meningkatkan sejumlah pengetahuan, juga merupakan suatu usaha yang sistematis dan terorganisasi untuk menyelidiki masalah tertentu yang memerlukan jawaban. Hakekat penelitian dapat dipahami dengan mempelajari berbagai aspek yang mendorong penelitian untuk melakukan penelitian. Setiap orang mempunyai motivasi yang berbeda, di antaranya dipengaruhi oleh tujuan dan profesi masing-masing. Motivasi dan tujuan penelitian secara umum pada dasarnya adalah sama, yaitu bahwa penelitian merupakan refleksi dari keinginan manusia yang selalu berusaha untuk mengetahui sesuatu. Keinginan untuk memperoleh dan mengembangkan pengetahuan merupakan kebutuhan dasar manusia yang umumnya menjadi motivasi untuk melakukan penelitian. Adapun tujuan Penelitian adalah penemuan, pembuktian dan pengembangan ilmu pengetahuan

\subsection{Jenis Penelitian}

Jenis penelitian yang di pakai dalam melakukan penelitian adalah jenis Penelitian Kualitatif, adalah penelitian tentang riset yang bersifat deskriptif dan cenderung menggunakan analisis, Setiap data kualitatif mempunyai karakteristiuknya sendiri. Data kualitatif berada secara tersirat di dalam sumber datanya. Sumber data kualitatif adalah catatan hasil observasi, transkrip interviu mendalam (depth interview), dan dokumen-dokumen terkait berupa tulisan ataupun gambar.

\subsection{Sumber Data}

Dalam penulisan proposal ini penulis menggunakan 2 sumber data yaitu sumber data primer dan sumber data sekunder Sumber data primer pengumpulan data primer merupakan data asli yang dikumpulkan oleh periset untuk menjawab 
masalah risetnya secara khusus. Survei dalam pemasaran data primer diperoleh secara langsung dari sumbernya sehingga periset merupakan "tangan pertama" yang memperoleh data tersebut,

\subsubsection{Sumber Data Primer}

\section{a. Metode Observasi / Praktek Langsung}

Metode observasi dilakukan penulis dengan cara pengamatan ketika terjun langsung di Lapangan. Metode ini menjadikan penulis mengerti dan melihat proses pengerjaan di tiap - tiap proyek yang sedang berjalan.

b. Wawancara / Tanya Jawab Supervisor Pembimbing Lapangan

Dalam metode ini penulis melakukan tanya jawab langsung kepada teknisinya apa materi yang belum dipahami. Karena dengan metode ini penulis mengerti saat pekerjaan proyek berlangsung, penulis lebih mengusai banyak ilmu yang dimiliki untuk penunjang dalam penulisan Laporan.

\subsubsection{Sumber Data Sekunder}

Metode pengambilan data sekunder Yaitu metode dengan cara melaku-kan survey langsung pada instansi-instansi atau perusahaan-perusahaan yang dianggap berkepentingan. Perusahaan itu dapat meliputi perusahaan bahan / material bangunan, konsultan, kontraktor, pemborong tenaga kerja, instansi yang menangani masalah jasa dan konstruksi bangunan serta perusa-haan-perusahaan lainnya yang bisa dijadikan bahan referensi.

\subsection{Teknik Pengambilan Data}

Dalam penulisan laporan skripsi ini penulis menggunakan teknik pengambilan data Dokumentasi dalam penelitian kualitatif kebanyakan diperoleh dari sumber manusia atau human resources, melalui observasi dan wawancara. Sumber lain yang bukan dari manusia (non-human resources), diantaranya dokumen, foto dan bahan statistik. Dokumen terdiri bisa berupa buku harian, notula rapat, laporan berkala, jadwal kegiatan, peraturan pemerintah, anggaran dasar, surat-surat resmi dan lain sebagainya.

Dari data-data yang telah dikumpulkan dilakukan analisa Rekayasa Nilai untuk menghasilkan adanya suatu peng-hematan biaya atau saving cost. Analisa Rekayasa Nilai dilakukan lima tahap,yaitu:

A) Tahap informasi pada tahap ini para estimator VE harus mengumpulkan datadata baik data primer berupa wawancara langsung dengan pihak terkait misalnya kontraktor, owner, konsultan, dan data sekunder berupa RAB, BOQ, master schedule dan referensi lainnya. Pengumpulan data dalam hal ini diperlukan untuk mengetahui pendapat dan masukan dari pihak-pihak yang berkepentingan dalam proyek serta dapat mengetahui karakteristik suatu proyek mulai dari item pekerjaan, 
harga satuan, volume pekerjaan, metode kerja, jenis peralatan dan jumlah pekerjas yang akan digunakan serta durasi waktu proyek.

B ) Tahap kreatif pada tahap ini tim VE diharapkan menggunakan inovasi dan kreatifitas dalam mengolah elemen biaya yang berpotensi menimbulkan kehilangan biaya (Loss Cost) dengan tetap mengacuh pada prinsip tidak mengurangi kinerja, keandalan, ketahanan, mutu, manfaat, fungsi dan estetika pada suatu elemen pekerjaan yang dipilih dalam penerapan rekayasa konsep VE, dimana pada tahap inilah biasanya yang paling sulit dalam implementasinya. Pada tahap ini akan melahirkan beberapa alternatif dan inovasi yang telah ditentukan yang kemudian dapat dijadikan pertimbangan dalam pengambilan suatu keputusan. Proses kreatifitas dan inovasi dalam tahap ini dapat diperoleh dari ilmu pengetahuan dasar (basic knowledge), pengalaman/ experiences, informasi-informasi terbaru dsb. Jika beberapa alternatif dari proses inovasi telah ditentukan maka dapat dilakukan suatu studi wawancara dan sharing pendapat dengan pihak-pihak yang paham/ahli terhadap alternatif yang akan diajukan untuk analisis lanjutan pada konsep VE.

C ) Tahap analisis fungsi Pada tahap ini dilakukan suatu analisis fungsi dengan mengidentifikasi elemen-elemen pekerjaan yang berpotensi memiliki tingkat biaya yang tinggi dengan melakukan breakdown cost terlebih dahulu dimana mengacu pada hukum Pareto. Hukum Pareto berbunyi $20 \%$ dari total item pekerjaan mewakili/terletak pada $80 \%$ dari total suatu anggaran proyek, dengan kata lain akan dilakukan proses seleksi item pekerjaan yang memiliki potensi biaya terbesar dalam suatu proyek. Kemudian setelah item pekerjaaan yang berpotensi VE telah diperoleh maka tahap selanjutnya dilakukan suatu proses analisis fungsi dengan menggunakan persamaan ratio Cost/ Worth (C/W) dimana menganalisis antara biaya elemen dengan biaya fungsi elemen tersebut.

Index Function Analysis $=$ Cost $/$ Worth

D ) Tahap Pengembangan/Development pada tahap ini dilakukan analisis lanjutan setelah terpilihnya suatu alternatif dalam proses rekayasa nilai pada elemen biaya yang akan direduksi. Tahap ini dilakukan dengan analisis Life Cicle Cost (LCC) yang berdasarkan pada analisis prediksi nilai uang terhadap waktu (Value Time of Money) yang berdasarkan pada estimasi suku bunga (Rate of Interest) dan durasi umur rencana, dengan tujuan untuk mengetahui manfaat jangka panjang dari beberapa alternatif inovasi yang telah ditentukan baik dari aspek prediksi biaya awal (Initial Cost), biaya perbaikan (Replacement/Repair Cost), biaya pemeliharaan dan operasional (Maintanance and Operational) serta prediksi biaya sisah (Salvage Cost), kemudian dilakukan analisis kumulatif terhadap biaya-biaya serta manfaat/benefit yang mungkin diperoleh selama umur dari alternatif yang akan dipilih. Alternatifalternatif tersebut kemudian dikumulatifkan secara keseluruhan dan selanjutnya dipertimbangkan jika memiliki potensi biaya yang terendah. Namun hal ini idak hanya dilihat dari aspek biaya saja melainkan harus dikaji secara komprehensif dari beberapa aspek penting lainnya. 
Sugianto. 2017. Rekayasa Nilai Pembuatan Terhadap Waktu dan Spesifikasi Pekerja Pada Pembangunan Perumahan pesona Tugu Rante Residence type 45 kabupaten blitar. Jurnal Qua Teknika, (2017), 7(1) : 31 41

Life Cycle Cost $(\mathrm{LCC})=($ - Initial Cost + Benefit/Revenue - Repair CostReplacement Cost - Maintanance/Operational Cost + Salvage)

E ) Tahap rekomendasi Tahap ini merupakan tahap penyajian dari hasil analisis pengambilan keputusan secara keseluruhan yang kemudian diserahkan kepada pihakpihak yang berotoritas dalam pengambilan keputusan dari alternatif VE tersebut

\section{HASIL DAN PEMBAHASAN}

\subsection{Identifikasi biaya tinggi}

Berdasarkan bagan biaya keseluruhan proyek,dapat di ketahui bobot pembiayaan setiap item pekerjaan pada proyek pembangunan perumahan pesona tugu rante residence yaitu seperti yang tertampil dalam tabel 1 tentang Breakdown,berdasarkan prinsip dasar hokum pareto yang menyatak bahwa $80 \%$ persen biaya tertinggi terletak pada $20 \%$ item pekerjaan biaya keseluruhan proyek berdasarkan dari biaya tinggi menunjukan bahwa item pekerjaan pasangan dan plesteran mempunyai nilai 48,265,042.00 (empat puluh delapan juta duaratus enam puluh lima ribu empat puluh dua rupiah )

\subsection{1 tabel analisa fungsi}

Berdasarkan hasil analisa fungsi darikeseluruhan item pekerjaan yang terpilih di atas di pilih 5 item pekerjaan yang mempunyai rasio C/W (cost / worth ) $\geq 2$, yaitu pekerjaan Galian Tanah Biasa, Pas. Pondasi Batu Kali 1pc : 6ps, Pas. Dinding 1pc : $3 \mathrm{kp}$ : 10ps, Plesteran dinding 1pc : 6ps,dan Dinding Keramik 20 x 25

\subsubsection{Tahap Kreatif}

Pada tahap ini dilakukan pengalian pengalian ide alternatif dalam penelitian ini penulis mengunakan 3 alternatif dari item pekerjaan yang telah di analisa pada tahap sebelumnya item pekerjaan itu adalah Galian Tanah Biasa, Pas. Pondasi Batu Kali 1pc : 6ps, Pas. Dinding 1pc : 3kp : 10ps, Plesteran dinding 1pc : 6ps,dan Dinding Keramik 20 x 25

\subsubsection{Tahap Analisa}

Pada seleksi analisa keuntungan dan kerugian ,ide ide yang telah di peroleh pada tahap kreatif di nilai berdasarkan keuntuungan dan kerugiannya secara subyektif kemudian pemberian bobot penilaian sesuai dengan parameter keuntungan dan kerugian yang di peroleh,penilaian dari setiap alternatif ide meliputi aspek biaya mutu,dan waktu pelaksanaan

Untuk memberikan rengking kepada setiap alternatif dalam analisa ini meliputi sebagai berikut:

1.Rengking tinggi di berikan utuk alternative yang memiliki nilai keuntungan pada biaya cost terendah,mempunyai keuntungan lebih banyak dan kerugian lebih sedikit. 2 Rengking rengking selanjutnya di berikan kepada alternatif -alternatif dengan keuntungan pada segi biaya yang lebih mahal dari rengking sebelumnya. 
Sugianto. 2017. Rekayasa Nilai Pembuatan Terhadap Waktu dan Spesifikasi Pekerja Pada Pembangunan Perumahan pesona Tugu Rante Residence type 45 kabupaten blitar. Jurnal Qua Teknika, (2017), 7(1) : 31 41

3 Rengkeng terendah di berikan kepada biaya biaya cost termahal.mempunyai keuntungan lebih sedikit dan kerugian banyak.

\subsubsection{Analisa Biaya Siklus Hidup}

Analisa biaya siklus hidup proyek untuk melakukan penilaian alternative alternative biaya berdasarkan kreteria biaya beberapa dasar untuk melakukan analisa ini adalah nilai ekonomi bangunan ini 15 tahun dan asumsi bunga $7 \%$

\subsubsection{Tahap rekomendasi}

Dalam tahap ini, metode penyampaian hasil studi rekayasa nilai dilakukan secara tertulis. Informasi diikhtisarkan secara ringkas dan jelas untuk mempermudahkan penyampaian. Dalam penyampaian, dicantumkan secara eksplisit perbandingan antara desain lama dengan desain usulan, keunggulan-keunggulan desain usulan dan besarnya penghematan. Besarnya penghematan didapatkan dengan mengurangkan analisa biaya desain lama

\subsection{Kesimpulan}

Dari hasil analisa Rekayasa Nilai pada proyek Pembangunan Perumahan Pesona Tugu Rante Residence Desa Bendo, Kecamatan Ponggok, Kabupaten Blitar Type 45, dapat diambil beberapa kesimpulan:

1. Pada pekerjaan Pasangan / plesteran, pekerjaan galian, pekerjaan lantai, pek cat catan dengan merubah jumlah pekerja dan waktu pengerjaan. Untuk item pekerjaan pas /plesteran dengan merubah waktu dan jumlah pekerja, menghasilkan penghematan biaya sebesar Rp. 8,632,287.00 dari biaya awal sebesar Rp. $48,265,042.00$. untuk item pekerjaan galian tanah dengan merubah waktu dan jumlah pekerja.menghasilkan penghematan biaya sebesar Rp 805,049.00 dari biaya awal sebesar Rp 3,954,474.23. untuk item pekerjaan lantai dengan merubah waktu dan jumlah pekerja.menghasilkan penghematan biaya sebesar $\mathrm{Rp} 1,538,833$ dari biaya awal sebesar Rp 8,402,700.00 untuk item pekerjaan cat catan dengan merubah waktu dan jumlah pekerja. menghasilkan penghematan biaya sebesar Rp 2,204,316 dari biaya awal sebesar Rp 7,830,881.00.Dari ke empat item pekerjaan tersebut dihasilkan penghematan total untuk 1 unit rumah sebesar Rp. 13,180,482.00 RAB semulah.

2. Dari beberapa tahap analisa rekayasa nilai yang dilakukan pada BAB IV terhadap item pekerjaan dapat di ketahui perbandingan waktu pekerjaan di lapangan dan pekerjaan yang telah di rekayasa dengan cara menambahkan pekerja dapat mengurangi waktu pengerjaan dan tidak melebihi dari harga rencana yang telah di tentukan.

\subsection{Saran}


Berdasarkan hasil analisa yang telah dilakukan dapat diberikan beberapa saran yang diharapkan berguna yang bisa dilakukan, yaitu sebagai berikut :

1. Penerapan Rekayasa Nilai hendaknya dilaksanakan pada awal proyek atau awal perencanaan pembangunan, se-hingga dapat memberikan hasil yang optimal.

2. Untuk penelitian selanjutnya, diharpkan ide-ide atau alternatif-alternatif yang didapat lebih banyak lagi, sehingga lebih dimungkinkan mencapai penghe matan mengumpulkan, merumuskan dan memecahkan suatu permasalahan untuk memperoleh hasil yang maksimal

\section{DAFTAR PUSTAKA}

[1]Dhanardono,B.2008.RekayasaNilai.Http://eprints.undip.ac.id/34006/5/1886_CHA PTER_II.pdf. 23 APRIL 2012

[2]Ir.Asiyanto,MBA.,IPM., “ConstructionProjrctCostManagement”,PenerbitPradnya Paramita, 2002.

[3] Rh. Mitchell \& S. Chandra, “Value Engineering”, Bandung, 1987.

[4]Saptono,A.AnalisisPenentuanBangunanAtasJembatandenganMetodeRekayasaNili. [5]http://matarancabuaya.files.wordpress.com/2011/08/contohproposal.pdf.23 APRIL 2012

[6]YantoIrawanST.,"PanduanPraktisMenghitungBiayaMembangunRumah",Penerbit KawanPustaka, 2010.

[7]Frederika,Ariany.2010.Analisis PercepatanPelaksanaan dengan Menambah Jam KerjaOptimum pada ProyekKonstruksi.Denpasar:Universitas Udayana

[8] Rahman,Irfanur. 2010.Earned Value AnalysisTerhadap Biaya pada Proyek PembangunanGedung. Surakarta.

[9]Vitriani.and Baknur, Farid. 2010. StudiPengendalian Proyek dengan Metode Konsep NilaiHasil(Studi Kasus pada Proyek PembangunanCauseaway Pelabuhan Curah GarongkongKab.Barru. Sulawesi Selatan.

[10]Rahman,Irfanur. 2010.Earned Value Analysis Terhadap Biaya pada Proyek Pembangunan Gedung. Surakarta: Universitas Sebelas Maret. 